\title{
Practice of and Thinking on Working and Learning Alternation Mode of Food Science Major in Higher Vocational Colleges
}

\author{
Xuguang Zhang \\ Xuzhou Vocational College of Industrial Technology, Xuzhou Jiangsu, 221140, China
}

Keywords: Food science major, Working and learning alternation mode, Practice and thinking.

\begin{abstract}
The mode of "combination of working and learning and college-industry cooperation" has been being the focus of attention and emphasis of the Ministry of Education. This mode mainly targets students of higher vocational colleges, and is adopted to tackle the difficulties of employment and labor shortage. For such a mode, favorable measures have been proposed and exercised, and good effects have been achieved.
\end{abstract}

\section{Introduction}

"Combination of working and learning" means an education mode in which learning and working are combined. This mode, involving students, enterprises and colleges, is to make full use of on-campus and off-campus resources, and combine the knowledge resources acquired at school and the practical experience obtained outside school together throughout education of college students. In the whole process, students learn theoretical knowledge and participate in learning activities at school as students; and work as "professionals" in reliance upon the learned knowledge in enterprises with compensation as other workers. Only in this way, students can truly blend themselves into society to steel themselves; will become more interested in their specialties; can know better about their specialties.

\section{Analysis of Demand for and Employment Situation of Talents of Food Science Major from Higher Vocational Colleges in China and Reasons thereof}

As China's food service industry gradually tends to be normalized, industrialized, serialized and scale expansion, the demand for talents of food science major increasingly rises. Surveys show that among the talents of food science major from all Chinese colleges and universities, those from higher vocational colleges are in short supply, because that the students applying for such colleges are relatively few due to difficulty of graduate employment. The main reasons for the difficulty of graduate employment of higher vocational college students are as below.

Deviation of Course Design of Colleges from Technologies Required by Enterprises.

According to the Chinese College Graduates' Employment Annual Report promulgated jointly by the Central School Department of the Communist Youth League of China and the Institute for Public Policy Research of Peking University, the main reason for the difficulty of graduate employment is that most colleges don't offer courses based on the skill requirements of enterprises. Thus, the best way to solve such problems is to promote "college-industry cooperation", namely teaching students based on enterprises' demands for talents, and making analysis of occupation posts; designing and arranging courses and publishing proper teaching materials based on the working processes, required post skills and requirements for workers' comprehensive quality of enterprises; cultivating talents with skills and knowledge most needed by enterprises to guarantee the quality of work in enterprises.

Deviation of Comprehensive Quality of Students of Colleges from Requirements for Talent Quality of Enterprises.

The comprehensive quality of most students of higher vocational colleges is low, while enterprises expect much about comprehensive quality of talents. The most prominent demerit of students of higher vocational colleges is poor initiative, which is mainly because that many students 
believe that what they learn at school has little to do with their future career, or is useless. The theory of "knowledge uselessness" is prevailing in many higher vocational colleges. A survey on higher vocational college students shows that most students are pro this theory. It is thus clear that students are dissuaded by the theory of "knowledge uselessness" from being active and initiative. Therefore, the best way to overcome such a problem is to implement "alternation of working and learning and college-industry cooperation" to make students realize the importance of theoretical knowledge, how studying at school is important, and that they can truly improve their abilities by studying only through actual practice.

\section{Poor Teaching Capability of Teachers of Colleges.}

There is an old saying: an accomplished disciple owes his accomplishment to his great teacher. In other words, teachers' capability will directly affect student's capability. Under the instruction of good teachers, good students are cultivated, and that a student appears to be of poor comprehensive quality is much probably because he has incompetent teachers. Most teachers of higher vocational colleges were differently transferred from ordinary universities without any exercise in enterprises. Though such kind of teachers have a solid knowledge base, they seldom have had practiced. Thus, it is hard for such kind of teachers to not impart ivory-towered knowledge to students. To rationally solve such problem, more chances should be given to teachers to exercise in enterprises by means of college-industry cooperation. Thus, teachers can steel themselves in enterprises in holidays or other free time to improve their teaching ability, which is good for both teachers and students.

\section{Exploration and Practice of "Combination of Learning and Working” in Food Science Major}

To make social demand for talents be in line with graduate employment demand, constant reform and innovation of "combination of working and learning" of food science major have been being made, and remarkable results have been made, as follows.

\section{Establish skill-oriented courses based on job requirements.}

Only by establishing courses based on the demands for talents of enterprises and industries, and hiring enterprise experts to design teaching materials suitable to students of higher vocational colleges, students can acquire knowledge to be applied in future work. Most of the previous teaching materials provide theoretical knowledge, and are seldom linked to practical application, adverse to students' practice. Thus, the teaching materials designed and compiled by related enterprises will be helpful, and meet the actual demand.

\section{Replace "concentrated practice" with "working and learning alternation".}

According to the regular length of schooling of higher vocational colleges, students study at school two years, and practice (employment practice) in enterprises one year. With such a mode, students hardly know the function of the knowledge learned at school in practical work, and then they may lose interest in learning. Furthermore, these students are unable to go back to school again once they realize their knowledge shortage. Thus, their development will be restrained. It is a good way to overcome such problems by adopting "working and learning alternation". In this way, students enter enterprises for practice in the first summer vacation to practice the basic knowledge and skills learned in the first semester; after the practice, students step into specialized knowledge learning phase in the second semester, when students can absorb knowledge faster and better because the previous practice helps students to combine learned theory and actual operation well; students enter enterprises again for practice in the winter vacation, to widen their horizon and improve their integrating skills; then, students will become clear about their career objectives to hunt job based on their capabilities and interests, which is favorable to their development.

\section{Issue "graduation certificate" and "skill certificate".}

Teaching quality depends on the teaching force, and the teaching force determines the quality of specialty construction. To improve the teaching force of food science major in China, it is necessary to have teachers take a temporary post for training or practice, so as to go into enterprises and learn about enterprises' demand for talents; hire enterprise experts as part-time tutors to provide training; 
regularly hold professional game specific to vocational skills, to arouse teachers' enthusiasm and improve students’ vocational skills.

\section{Results of Application of "Working and Learning Alternation” Mode in Food Science Major in Higher Vocational Colleges}

\section{"Working and learning alternation" pushed forward the construction of food science major.}

Comparing with undergraduate course universities, the higher vocational colleges attach more importance to practical teaching in specialty construction. The latter adopt the mode of working and learning alternation to strive for social recognition of both colleges and enterprises. Only in this way, it can be guaranteed that talent cultivation is in line with social demand for talents, and the specialty construction of colleges meets the social development trend. College-industry cooperation requires enterprises to join in the deign and preparations for teaching and teaching materials, which is favorable to colleges following closely the development pace of enterprises to design specialty structure and course structure oriented by employment, make talent cultivation scheme and teaching program in line with enterprises' demand for talents, and train students to meet the requirements of society and jobs. As to enterprises, productive tasks tend to be changeful and temporary. For this reason, it is necessary to adopt the mode of working and learning alternation to adjust teaching plans from time to time. Food processing covers dairy products, beverage, meat products, vegetables, etc. Besides, the specialty can be distinguished by means of working and learning alternation. The teaching and research office ought to make discussions and modifications every year, and determine main courses to facilitate working and learning alternation before students enter enterprises. Thus, students can find answers to their questions by themselves via practice. At last, the course contents and teaching plans also ought to be adjusted based on job requirements from time to time.

"Working and learning alternation" quickened the construction of teaching staff.

Most teachers of higher vocational colleges were differently transferred from ordinary universities without any training, who know little about particular situations of enterprises. By means of working and learning alternation, teachers can go into workshop to learn about working process and management mode of enterprises, so as to know more about enterprises and improve their operational ability; know more about the up-to-date technology of enterprises. Thus, working and learning alternation is helpful to train excellent vocational teachers, and consolidate teaching staff. skills.

“Working and learning alternation” improved students' specialized quality and vocational

Vocational education refers to emphasizing vocational skill training while imparting theoretical knowledge. Working and learning alternation has changed the traditional education mode in which theory and classroom teaching overweigh practice, from basic education to skill education, and from general training to comprehensive skill training. On the contrary, theoretical knowledge is combined with actual operation, so that students get improved in comprehensive quality including theoretical knowledge, operational ability, work capacity, sociability and team spirit. The mode of working and learning alternation will make for students developing a knowledge base desired by enterprises, so that graduates are welcomed by enterprises. Thus, working and learning alternation also is helpful to broaden the employment channel.

\section{Building a teaching staff for promoting “working and learning alternation” is of great significance to the development of food science major of higher vocational colleges}

\section{Send out teachers for further study.}

Further study refers to, on one hand, acquiring advanced theoretical knowledge as postgraduate student; on the other hand, learning about new technologies and improving comprehensive abilities by going into enterprises for practice and training by documents. 


\section{Send out teachers to take a temporary post in enterprises for tempering.}

The on-campus productive training base is usually in the charge of specialized teachers. Thus, specialized teachers ought to learn to manage company, and take the post of general manager or technical director, etc., to temper themselves. Only experienced teachers can manage the training bases well to create high economic profit.

\section{Hire part-time teachers.}

Professionals of enterprises are proficient in operation. Thus, professionals of enterprises will do better than teachers to teach new technologies to students.

\section{Considerations for Implementing "working and learning alternation and college-industry cooperation" mode}

\section{Cautiously select enterprises.}

In college-industry cooperation, enterprises play an important role. Thus, it is important to select proper enterprises for cooperation. The selected enterprises should be able to provide posts suited to colleges' training with compensation, equip related devices, offer technical training, and meet students' learning needs. The cooperative enterprises are supposed to have complete management system, assessment system and management assessment system.

Give play to the function of food science major teaching commission.

Though a food science major teaching commission was established, it appears as a decoration. The management and technicist hired by the commission from cooperative enterprises ought to be allowed to carry out material education reform, participate in the making of training scheme of professionals, and strengthen professional skill training of students jointly with colleges.

\section{Establish a rational teaching evaluation mechanism.}

Presently, most higher vocational colleges have no complete material teaching evaluation system specific for food science major. Instead, students' performance is evaluated solely based on practice report, or by a meeting on working and learning alternation. Actually, students' working attitude and learning motivation also should be covered in evaluation, so as to promote integrated development and social adaption ability of students.

\section{Conclusion}

To sum up, "working and learning alternation, and college-industry cooperation” is a good way to mitigate the difficulty of employment of graduates of food science major from higher vocational colleges. In this mode, students can apply the learned knowledge to work, and become more enthusiastic for learning. For enterprises, the ability training of students is of great importance, because it is related to enterprises' future development; for colleges, "college-industry cooperation" is more important, because the employment rate of graduates can be raised, and colleges and enterprises can benefit each other and make progress together in this way only.

\section{References}

[1] Huang Guangjun, Liu Rong, Zong Bao, et al. Optimization and Innovation of “College-Industry Cooperation and Working and Learning Alternation” Mode of Food Science Major of Higher Vocational Colleges, Guangdong Chemical Industry,2012,39(5):260-260,262.

[2] Liu Jing, Zhang Kaiping. Practice of and Thinking on Working and Learning Alternation Mode of Food Science Major in Higher Vocational Colleges, Inner Mongolia Science Technology and Economy,2016,(2):24,26.

[3] Lin Jie. Primary Exploration in the Teaching Mode of "Working and Learning Alternation” plus “Order-oriented Training”, Nan Fang Lun Kan,2009,(7):111-112. 